\title{
KEDUDUKAN PIDANA KEBIRI DALAM SISTEM PEMIDANAAN DI INDONESIA (PASCA DIKELUARKANYA PERPPU No. 1 TAHUN 2016)
}

\author{
Aditia Arief Firmanto \\ Fakultas Hukum Universitas Malahayati Bandar Lampung \\ aditiaArieffirmanto@yahoo.co.id
}

\begin{abstract}
Abstrak
Salah satu pidana tindakan bagi pelaku kejahatan seksual terhadap anak antara lain adalah pidana kebiri, hadirnya pidana kebiri dalam Sistem Pemidanaan di Indonesia diatur dalam Perppu No. 1 Tahun 2016, tujuan dikeluarkanya Perppu No. 1 Tahun 2016 dimaksudkan untuk mengatasi kegentingan yang diakibatkan terjadinya kekerasan seksual terhadap anak yang semakin meningkat secara signifikan, selain itu juga untuk memberikan efek jera bagi pelaku dan memberikan pembinaan dan pemulihan kepada pelaku pedofilia serta mengingatkan kepada masyarakat untuk tidak berbuat tindak pidana tersebut. Kedudukan Pidana Kebiri dalam sistem Pemidanaan di Indonesia termasuk kedalam Pidana tindakan, hal ini sesuai dengan Perppu No. 1 Tahun 2016 Pasal 81 Ayat 7. Sedangkan relavansi pidana kebiri dalam Teori Pemidanaan di Indonesia adalah relevan menjadi alternatif pidana terahir (ultimum remidium) bagi pelaku pedofilia, walaupun pidana kebiri memang belum ada dalam sistem pemidanaan di Indonesia. Dengan adanya Perppu No. 1 Tahun 2016 menjadi jenis pidana yang baru dalam sistem pemidanaan dan memberikan masukan bagi Pembaharuan Hukum Pidana di Indonesia untuk memasukan pidana kebiri dalam jenis Pidana Tindakan. Selain itu eksekutor terhadap pelaku pidana Kebiri dilakukan oleh Kepolisian Republik Indonesia melalui Dokter Kepolisian (Dokpol), sedangkan pertanggungjawaban teknis pelaksanaan kebiri oleh Dokter Kepolisian dipertanggungjawabkan kepada negara.
\end{abstract}

Kata Kunci: Pidana Kebiri; Sistem Pemidanaan; Dokter Kepolisian

\begin{abstract}
One of the punishment acts for sexual violence against children, among others, is castration. The existence of castration in the punishment system in Indonesia is set in the government regulation (Perppu) No. 1 Year of 2016. The purpose of the regulation is intended to be a solution for sexual crimes against children which had increased at an alarming rate, and to provide a deterrent effect for offenders and provide guidance and healing to pedophiles and warned the people not to commit the offense. The position of castrations in the punishment system of Indonesia is stipulated into the criminal acts. It is related to the government regulation No. 1 Year of 2016 Article 81 Paragraph 7. Meanwhile, the relevance of castrations in the theory of punishments in Indonesia is becoming the last alternative punishment (ultimum remedium) for the pedophiles. Although the castration regulation does not exist in the punishment system
\end{abstract}


in Indonesia, the issuance of Perppu No. 1 Year of 2016 has become a new kind of punishment and provides inputs for the criminal Law reforms in Indonesia to include the castration into the criminal acts. Besides, the executor of the criminal offender of castration is carried out by the Indonesian National Police trough the Police Doctor, meanwhile the technical implementation of the castraction which is carried out by the Police Doctor is guaranteed by to goverment.

Keywords: Castrations; Punishment system; Police Doctor

\section{A. PENDAHULUAN}

Dewasa ini masyarakat sering disajikan kasus-kasus kejahatan seksual terhadap anak dari berbagai media baik cetak maupun elektronik. Pelaku kejahatan seksual terhadap anak yang biasa disebut dengan pedofilia adalah perbuatan seksual yang dilakukan oleh orang dewasa terhadap anak (berusia dibawah 15 tahun) sebagai kepuasan seks yang didapatkan oleh orang dewasa dari hubungan seks dengan anak-anak (Irianto, 2010: 101).

Menurut catatan tahunan 2016 Komnas Perempuan, dari kasus kekerasan terhadap perempuan, kekerasan seksual berada di peringkat kedua dengan jumlah kasus mencapai 2.399 kasus (72\%), pencabulan mencapai 601 kasus (18\%), sementara pelecehan seksual mencapai 166 kasus (5\%) (Muhamad dan dwi, "Pemerkosaan Berjamaah, Indonesia Darurat Kekerasan", http://m.dw.com/id/pemerkosaan-berjamaah-Indonesia-darurat-kekerasanseksual/a-19233807, diakses pada Kamis, 23 Juni 2016, jam 19.30 wib).

Beberapa contoh kasus-kasus kejahatan seksual terhadap anak di antaranya yaitu :

1. Kasus di Sleman Yogyakarta dengan pelaku H, YRA, KA, ADR, TN, JN, dan BBG terhadap Riya Puspita Restanti 18 April 2013 (Chatarina Binarsih, "Ini Kisah Tragis Siswi SMK yang Diperkosa lalu dibakar 2 kali, http://jogja.tribunnews.com/2013/04/19/ini-kisah-tragis-siswi-smk-yangdiperkosa-lalu-dibakar-2-kali, diakses pada Kamis, 23 Juni 2016, jam 19.35 wib);

2. Kasus Jakarta International School (JIS) di Jakarta dengan pelaku Neil Bantleman dan Ferdinant Michael terhadap MAK, AL dan DA pada 24 Maret 2014 (Arief Zulfian, "Kronologis Kasus JIS", http://m.kompasiana.com/ariefzulfian/kronologis-kasusis 55e5775622afbd26054e49da, diakes pada Kamis, 23 Juni 2016, jam 19.50 wib);

3. Kasus di Jakarta dengan pelaku Saipul Jamil terhadap DS pada 18 Februari 2016 (Aditia Saputra dan Fahrurozi, "Begini Kronologi Dugaan Pelecehan yang Dilakukan Saiful Jamil", http://m.liputan6.com/showbiz/read/2439571/begini-kronologi-dugaanpelecehan-yang-dilakukan-saipul-jamil, diakses pada Kamis, 23 Juni 2016, jam 20.00 wib); 
4. Kasus di Bengkulu dengan pelaku 14 orang terhadap Yuyun pada 2 April 2016 (Demon Fajri, "Ini Kronologi Pemerkosaan Yuyun di Bengkulu", http://m.okezone.com/read/2016/05/04/340/1380243/ini-kronologipemerkosaanyuyun-di-bengkulu, diakses pada Kamis, 23 Juni 2016, jam 20.10 wib);

5. Kasus di Tangerang dengan pelaku RAL, Rahmat Ariefin, Imam Harpiadi terhadap Eno Parihah pada 12 Mei 2016 (Andri Donnal Putera, "Ini Kronologi Pembunuhan EF, Perempuan yang Tewas Mengenaskan di Tangerang", http://megapolitan.kompas.com/read/2016/05/16/13480371/Ini.Kronologi. Pembunuhan.EF.Perempuan.yang.Tewas.Mengenaskan.di.Tangerang, diakses pada Kamis 23 Juni 2016, jam 20.20 wib).

Dari beberapa contoh kasus di atas ada yang sedang dalam proses penyidikan (kasus Yuyun dan Eno), ada pula yang sudah dijatuhkan vonis, yaitu kasus Saipul Jamil. Ia divonis 3 tahun pidana penjara oleh Pengadilan Negeri Jakarta Utara dengan dikenakan pasal 292 KUHP, namun putusan tersebut belum mempunyai kekuatan hukum tetap (Incracht) karena pihak Saipul Jamil melakukan upaya hukum banding. Sementara itu untuk kasus Riya, dari enam pelaku beberapa pelaku divonis oleh Mahkamah Agung dengan hukuman paling berat hukuman mati yaitu $\mathrm{H}$, YRA dan KA. Ketiganya dijerat dengan Pasal 340 KUHP tentang Pembunuhan Berencana. Namun untuk pelaku $\mathrm{H}$ belum bisa dieksekusi karena melakukan upaya hukum Peninjauan kembali, sedangkan 2 pelaku lainya menunggu eksekusi mati. Kemudian untuk kasus JIS para pelaku divonis 11 Tahun pidana penjara oleh Mahkamah Agung dengan dikenakan Pasal 82 UU No.23 tahun 2002 Jo. UU No. 35 Tahun 2014 tentang Perlindungan Anak.

Pengaturan tindak pidana pedofilia diatur menggunakan ketentuan umum di dalam KUHP Pasal 290 dan 292

Pasal 290 KUHP berbunyi:

"Dipidana dengan Pidana Penjara selama-lamanya 7 tahun;

1. Barang siapa melakukan tindakan-tindakan melanggar kesusilaan dengan seorang yang ia ketahui bahwa orang tersebut sedang dalam keadaan pingsan atau sedang berada dalam keadaan tidak berdaya;

2. Barang siapa melakukan tindakan melanggar kesusilaan dengan seorang yang ia ketahui atau sepantasnya harus dapat ia duga bahwa orang tersebut belum mencapai usia lima belas tahun, atau jika tidak dapat diketahui usianya, orang tersebut belum dapat dinikahi;

3. Barang siapa membujuk seseorang yang ia ketahui atau sepantasnya ia duga bahwa orang tersebut belum mencapai usia lima belas tahun atau jika tidak dapat diketahui usianya, orang tersebut belum dapat dinikahi untuk melakukan atau untuk membiarkan dilakukan tindakan-tindakan yang melanggar kesusilaan, atau untuk melakukan hubungan kelamin di luar pernikahan dengan pihak ketiga."

Pasal 292 KUHP berbunyi : 
"orang dewasa yang melakukan suatu tindakan melanggar kesusilaan dengan anak yang belum dewasa dari jenis kelamin yang sama, yang sebelum kedewasaanya ia ketahui atau sepantasnya harus ia duga, dipidana dengan pidana penjara selama lamanya lima tahun."

Kemudian juga diatur secara khusus dengan UU No. 23 Tahun 2002 Jo. UU No. 35 Tahun 2014 tentang Perlindungan Anak Pasal 81, yaitu:

"orang yang dengan sengaja melakukan kekerasan atau ancaman kekerasan memaksa anak untuk melakukan persetubuhan denganya diancam hukuman maksimal lima belas tahun penjara."

Dilihat dari karakteristik perbuatan pelaku pedofilia, bisa dikatakan anakanak dieksploitasi sebagai korban. Secara yuridis pihak yang dituntut bertanggungjawab adalah eksploitatornya atau pelakunya. Selama ini undangundang yang sering dipakai untuk mengadili penjahat kekerasan seksual adalah dengan KUHP Pasal 292 Jo. Pasal 64 tentang pencabulan. Tuntutan maksimal 5 tahun penjara dipandang Komnas Anak sudah tidak relevan untuk memberikan efek jera bagi si pelaku serta mengandung kelemahan yang diatur hanya orang dewasa membujuk anak (Davit Setyawan, "Indonesia Darurat Kejahatan Seksual Anak", www.voaindonesia.com/a/kpai-kekerasan-seksual-terhadap-anak-sudahdarurat/1902840.html, diakses pada Jumat, 24 Juni 2016, jam 19.00 wib).

Selain itu dalam Pasal 287 KUHP disebutkan dengan sanksi maksimal 9 tahun penjara, namun dalam hal tidak ada pengaduan, maka penuntutan tidak akan dilakukan. Hal ini tentunya menjadi titik lemah dalam KUHP karena pada kenyataanya, korban terkadang memang tidak melaporkan kejadian tersebut dengan berbagai alasan seperti ancaman dan rasa malu.

Pasal-Pasal tersebut nyatanya tidak memberikan efek jera bagi pelaku pedofilia. Hal ini dibuktikan dengan semakin banyak dan maraknya kasus kekerasan/pelecehan seksual terhadap anak. Pidana yang berlaku dari tahun ketahun tidak mengalami perubahan. Hal ini merupakan kelemahan hukum yang ada karena pidana yang seharusnya bisa memberikan perlindungan dan pencegahan menjadi tidak lagi berfungsi sebagaimana mestinya. Oleh karenanya perlu adanya suatu upaya hukum yang baru untuk memberikan efek jera sekaligus sebagai tindakan pencegahan agar bisa mengurangi bahkan tidak terjadi lagi kasus kekerasan seksual terhadap anak. Salah satu upaya hukum tersebut adalah dengan melakukan pembaharuan hukum pidana dan mencantumkan hukuman kebiri sebagai hukuman bagi pelaku pedofilia.

Pembaharuan hukum pidana merupakan suatu upaya untuk melakukan reorientasi dan reformasi hukum pidana sesuai dengan nilai-nilai sentral sosiopolitik, sosiofilosofis dan sosiokultural masyarakat Indonesia yang melandasi kebijakan sosial, kebijakan kriminal dan kebijakan penegakan hukum di Indonesia. Secara singkat dapat dikatakan, bahwa pembaharuan hukum pidana pada hakikatnya harus ditempuh dengan pendekatan yang berorientasi pada kebijakan (policy oriented opproach) dan sekaligus pendekatan yang berorientasi pada nilai (value oriented approach) (Arief, 2010: 29). 
Pembaharuan Hukum Pidana harus dilakukan dengan pendekatan kebijakan, karena memang pada hakikatnya ia hanya merupakan bagian dari kebijakan atau policy. Jika setiap kebijakan terkandung pula pertimbangan nilai, maka pembaharuan hukum pidana harus pula berorientasi pada pendekatan nilai (Arief, 2010: 29)

Berdasarkan uraian di atas dapat disimpulkan kemudian makna dan hakikat pembaharuan hukum pidana sebagai berikut (Arief, 2010: 30):

1. Dilihat dari sudut pendekatan kebijakan

a. Sebagai bagian dari kebijakan sosial, pembaharuan hukum pidana pada hakikatnya merupakan bagian dari upaya untuk mengatasi masalahmasalah sosial termasuk masalah kemanusiaan dalam rangka mencapai/menunjang tujuan nasional yaitu kesejahteraan masyarakat dan sebagainya;

b. Sebagai bagian dari kebijakan kriminal, pembaharuan hukum pidana pada hakikatnya merupakan bagian dari upaya perlindungan masyarakat khususnya upaya penanggulangan kejahatan;

c. Sebagai bagian dari kebijakan penegakan hukum, pembaharuan hukum pidana pada hakikatnya merupakan bagian dari upaya memperbaharui substansi hukum (legal substance) dalam rangka lebih mengefektifkan penegakan hukum.

2. Dilihat dari sudut pendekatan nilai

Pembaharuan hukum pidana pada hakikatnya merupakan peninjauan dan penilaian kembali (reorientasi dan reevaluasi) nilai-nilai sosiopolitik, sosiofilosofis, sosiokultural yang melandasi dan memberi isi terhadap muatan normatif dan substansi hukum pidana yang dicita-citakan, misalnya KUHP baru sama saja dengan orientasi nilai dari hukum pidana lama warisan penjajah (KUHP lama atau WvS).

Selain itu, pembaharuan hukum pidana juga diatur dalam KUHP Pasal 103 yang berbunyi bahwa "ketentuan-ketentuan dari kedelapan Bab I dalam buku I berlaku juga atas peristiwa yang padanya ditentukan pidana menurut ketentuan perundangan lainya kecuali kalau dalam Undang-Undang atau Peraturan Pemerintah ditentukan lain". Berdasarkan ketentuan ini dimungkinkan dibuat aturan hukum pidana di luar KUHP dalam memenuhi kebutuhan masyarakat, asalkan tidak bertentangan dengan aturan hukum yang telah dikodifikasi dalam KUHP (Djamali, 2007: 190).

Upaya pembaharuan hukum pidana dalam hal kasus tindak pidana kekerasan seksual pada anak atau pelaku pedofilia ini adalah dengan memberikan pidana kebiri sebagai upaya hukum untuk memberikan efek jera bagi pelaku. Kebiri disebut juga pengebirian atau kastrasi, yaitu tindakan bedah atau kimia yang bertujuan untuk menghilangkan fungsi testis pada laki-laki atau fungsi ovarium pada perempuan. Kebiri, baik itu pada manusia atau hewan adalah dengan cara memotong saluran testis makhluk hidup (hewan, manusia) sehingga tidak lagi menghasilkan sperma. Kebiri kimiawi adalah pengebirian dengan cara menyuntik 
seorang laki-laki dengan obat-obatan yang secara efektif menyebabkan tumpulnya gairah seks untuk jangka waktu tertentu. Pidana kebiri ini menjadi alasan sebagai upaya hukum baru terhadap pelaku tindak pidana pedofilia, karena di Indonesia kejahatan seksual terhadap anak ahir-ahir ini begitu meluas dan sudah sangat banyak kasus kejahatan seksual terhadap anak yang terjadi di Indonesia (Dian Maharani, "Yang Terjadi Jika Seseorang Dihukum Kebiri", http://health.kompas.com/read/2015.10/22/120535623/Yang.Terjadi.jika.seseora ng.Dihukum.Kebiri, diakses pada Sabtu, 25 Juni 2015, jam 19.30 wib).

Pidana kebiri bukanlah pidana yang baru karena telah ada beberapa negara yang menerapkan pidana tersebut bagi pelaku kejahatan seksual. Sebagai contohnya Negara Bagian California yang telah menerapkan pidana kebiri sejak tahun 1996. Negara bagian lain yang telah menerapkan hukuman ini adalah Georgia, Lowa, Montana, Oregon, Texas dan Wiconsin. Pidana kebiri kimiawi pada beberapa Negara Bagian tersebut bisa dilaksanakan tergantung pada putusan pengadilan. Selain Negara Bagian Amerika Serikat, masih ada beberapa Negara yang telah menerapkan hukuman kebiri kimiawi yaitu Polandia, Moldova, Israel, Argentina, Estonia, Australia, Korea Selatan, dan Rusia. Sedangkan di Indonesi, pidana kebiri dikeluarkan kebijakannya oleh Presiden Joko Widodo melalui Perppu No. 1 Tahun 2016. Korban yang notabene adalah anak-anak yang seharusnya mendapat perlindungan justru mendapat perlakuan yang bisa memberikan dampak trauma psikologis secara berkepanjangan hingga ia dewasa sampai seumur hidupnya, dan menjadikan anak tersebut kehilangan masa depanya akibat trauma. Bahkan tidak jarang korban setelah dewasa dapat menjadi pelaku pedofilia karena rasa traumatis dan sifat dendam yang sulit dihilangkan. Oleh karena itu perlu ada hukuman yang bisa memberikan rasa keadilan yang setimpal bagi korban terhadap apa yang dilakukan oleh pelaku tindak pidana pedofilia (Nafsiah, "Ini 9 Negara Yang Menerapkan Sanksi Untuk Pelaku Kejahatan Seks", http://m.detik.com/news/berita/2583289/ini-9-negara-yang-menerapkan-sanksikebiri-untuk-pelaku-kejahatan-seks/4\#detailfoto, diakses pada Sabtu, 25 Juni 2016, jam 19.45).

Dari uraian di atas penulis dapat merumuskan menjadi tiga pertanyaan, yang pertama (1) bagaimana kedudukan pidana kebiri dalam sistem pemidanaan di Indonesia?; (2) bagaimana relevansi pidana kebiri dalam teori pemidanaan?; (3) siapa yang mengeksekusi (eksekutor) pidana kebiri. Jenis penelitian dalam penulisan hukum ini adalah penelitian hukum normatif atau penelitian kepustakaan yaitu penelitian hukum dengan cara meneliti bahan-bahan pustaka atau data sekunder yang terdiri dari bahan hukum primer.

\section{B. PEMBAHASAN}

\section{Kedudukan Pidana Kebiri Dalam Sistem Pemidanaan di Indonesia}

Pasca kemerdekaan, baik pada masa orde lama maupun orde baru, KUHP warisan Belanda ini masih tetap berlaku, padahal KUHP yang diberlakukan di Indonesia pada praktiknya sudah tidak sesuai dengan kondisi masyarakat Indonesia 
sekarang. Kenyataan inilah yang menyebabkan kebutuhan untuk melakukan pembaharuan hukum pidana di Indonesia. Kondisi perubahan hukum yang adil dan sesuai dengan kenyataan yang berakar dari nilai-nilai yang ada dalam masyarakat kemudian secara tegas juga dinyatakan dalam konsideran Rancangan Kitab UndangUndang Hukum Pidana (RKUHP) yang menyatakan bahwa materi hukum pidana nasional harus disesuaikan dengan politik hukum, keadaan dan perkembangan kehidupan berbangsa dan bernegara bangsa Indonesia. Sementara tujuan penyusunan hukum pidana dinyatakan sebagai perwujudan upaya pembaharuan hukum nasional Negara Republik Indonesia yang berdasarkan Pancasila dan UUD 1945, serta untuk menghormati dan menjunjung tinggi Hak Asasi Manusia (Tongat, 2010: 48).

Penjelasan umum RKUHP juga menyatakan bahwa penyusunan Kitab UndangUndang Hukum Pidana (KUHP) Nasional untuk menggantikan KUHP peninggalan Pemerintah Kolonial Belanda dengan segala perubahanya merupakan salah satu usaha dalam rangka pembangunan hukum nasional. Usaha tersebut dilakukan secara terarah dan terpadu agar dapat mendukung pembangunan nasional di berbagai bidang, sesuai dengan tuntutan pembangunan serta tingkat kesadaran hukum dan dinamika yang berkembang dalam masyarakat.

Namun selama ini belum ada rumusan tentang tujuan pemidanaan dalam hukum positif di Indonesia. Akibat tidak adanya rumusan pemidanaan ini menyebabkan banyak sekali rumusan dan jenis sanksi pidana yang tidak konsisten dan tumpang tindih. RKUHP yang telah disusun nampaknya akan mengalami problem yang sama dimana kecendrungan adanya pencampuran konsep pemidanaan dan penetapan sanksi. Persoalan penetapan sanksi dalam RKUHP Indonesia, dalam sejarahnya, mengalami beberapa kali perubahan, tercatat lebih dari delapan konsep RKUHP yang dalam beberapa konsepnya mempunyai persamaan namun juga terdapat perbedaan.

Menurut penulis, hal ini menunjukan bahwa konsep pemidanaan dan penetapan sanksi dalam RKUHP selalu mengalami perubahan dari waktu ke waktu. Adanya perubahan yang cukup mendasar dari konsep awal sampai dengan konsep yang terakhir menunjukan bahwa persoalan pemberian sanksi dalam RKUHP selalu disesuaikan dengan perkembangan kondisi kehidupan berbangsa dan bernegara. Barda Nawawi Arief menyatakan bahwa hubungan antara penetapan sanksi pidana dan tujuan pemidanaan adalah titik penting dalam menentukan strategi perencanaan politik kriminal. Menentukan tujuan pemidanaan dapat menjadi landasan untuk menentukan cara, sarana atau tindakan yang akan digunakan (Arief, 2011: 21).

Kebijakan menetapkan sanksi pidana apa yang dianggap paling baik untuk mencapai tujuan, setidak-tidaknya mendekati tujuan, tidak dapat dilepaskan dari persoalan pemilihan berbagai alternatif sanksi. Masalah pemilihan berbagai alternatif untuk memperoleh pidana mana yang dianggap paling baik, paling tepat, paling patut, paling berhasil atau efektif merupakan masalah yang tidak mudah. Dilihat dari sudut politik kriminal, tidak terkendalinya perkembangan kriminalitas 
yang semakin meningkat, justru dapat disebabkan oleh tidak tepatnya jenis sanksi pidana yang dipilih dan ditetapkan (Arief, 2011: 22)

Rancangan KUHP menganut sistem pemidanaan dua jalur (double track system) di mana di samping pelaku tindak pidana dapat dijatuhi sanksi pidana (criminal punishment) dapat juga dikenakan berbagai tindakan (treatment). Selain itu dalam jenis-jenis pemidanaan dalam RKUHP juga bertambah dengan adanya pidana pengawasan dan pidana kerja sosial yang merupakan bagian dari pidana pokok, jenis tindak pidana yang sebelumnya belum pernah dikenal dalam KUHP Indonesia. Selain itu RKUHP juga memasukan beberapa ketentuan yang berkaitan dengan pemidanaan denda adat yang mempunyai rumusan tidak rinci dan sangat tergantung pada putusan hakim. RKUHP sejak awal terlihat tidak konsisten dalam menentukan tujuan pemidanaan dan penetapan sanksi-sanksinya.

Salah satu bentuk Pemidanaan lainya yang ahir-ahir ini hangat dibicarakan adalah Pidana Kebiri. Kedudukan Pidana kebiri dalam sistem pemidanaan di Indonesia bukanlah sebagai pidana pokok, tambahan maupun pemberatan, namun termasuk dalam pidana tindakan. Pasal 81 ayat 7 Perppu No. 1 Tahun 2016 menegaskan, "terhadap pelaku sebagaimana dimaksud pada ayat (4) dan ayat (5) dapat dikenai tindakan berupa kebiri kimia dan pemasangan cip". Bunyi dari Pasal 81 ayat 7 tersebut tidak dapat dipahami secara terpisah-pisah, sebab rujukanya yang dapat dikenai pidana tindakan bagi pelaku pedofilia harus dilihat kembali pada ayat sebelumnya, yaitu ayat 4 dan ayat 5 . Ketentuan ini pada intinya mengatur jenis tindak pidana kekerasan seksual terhadap anak berdasarkan siapa pelaku (ayat 4) dan akibat dari perbuatan petindaknya (ayat 5). Jika pelaku kekerasan seksual terhadap anak ternyata seorang residivis, maka dapat dikenai tindakan berupa kebiri kimia. Hal demikian juga berlaku pada pelaku yang berdasarkan akibat dari perbuatan pelaku, yakni menimbulkan korban lebih dari satu orang, mengakibatkan luka berat, gangguan jiwa, penyakit menular, hilangnya fungsi reproduksi, dan/atau korban meninggal dunia, kepada pelaku ini dikenakan pidana tindakan kebiri kimia.

Perbedaan pidana pemberatan dan pidana tambahan berdasarkan Perppu No.

1 Tahun 2016 terletak pada Pasal 81 ayat 3 dan 4 yang menyatakan bahwa:

Pasal 81 ayat (3)

"Dalam hal tindak pidana sebagaimana dimaksud pada ayat (1) dilakukan oleh orang tua, wali, orang-orang yang mempunyai hubungan keluarga, pengasuh anak, pendidik, tenaga kependidikan, aparat yang menangani perlindungan anak, atau dilakukan oleh lebih dari satu orang secara bersama-sama, pidananya ditambah $1 / 3$ (sepertiga) dari ancaman pidana sebagaimana dimaksud pada ayat (1)

\section{Pasal 81 ayat 4}

"Selain terhadap pelaku sebagaimana dimaksud pada ayat (3), penambahan 1/3 (sepertiga) dari ancaman pidana juga dikenakan kepada pelaku yang pernah dipidana karena melakukan tindak pidana sebagaimana dimaksud dalam pasal $76 \mathrm{D}^{\prime \prime}$. 
Adanya frasa "pidananya ditambah $1 / 3$ (sepertiga)" dari ancaman pidana sebagaimana dimaksud pada ayat 1 , maka mereka yang dapat dikenakan pidana pemberatan yakni digantungkan pula pada jenis pelakunya. Bahwa yang termasuk kerabat dekat anak dan pelaku residivis dalam tindak perbuatan kekerasan seksual terhadap anak dikenakan pemberatan hukuman melalui penambahan sepertiga (1/3) dari ancaman pidana penjara 5 hingga 15 tahun dan tambahan sepertiga (1/3) dari ancaman pidana denda paling banyak Rp. 5.000.000.000 (lima milyar rupiah).

Adapun yang termasuk dalam pidana tambahan dalam Pasal 81 ayat 6 Perppu No. 1 Tahun 2016 yaitu, "selain dikenai pidana tambahan dimaksud ayat (1), ayat (3), ayat (4), dan ayat (5), pelaku dapat dikenai pidana tambahan berupa pengumuman identitas pelaku". Pidana tambahan jenis ini dapat dikenakan kepada jenis pelakunya sebagai pelaku biasa, pelaku yang dekat dengan anak, pelaku residivis dan karena akibat dari perbuatan pelaku. Sehingga dimungkinkan pelaku pedofilia terutama residivis dan petindak yang berdasarkan akibat perbuatanya terjerat dalam pidana pemberatan, terjerat pula dengan pidana tambahan, dan terjerat lagi dengan pidana tindakan.

Perlu diketahui, dimengerti, dan dipahami dalam kaitanya dengan Perppu No. 1 Tahun 2016 bahwa tindak pidana kekerasan seksual terhadap anak yang memungkinkan dikenakan hukuman tindakan berupa kebiri kimia, hanyalah tindak pidana yang tergolong sebagai persetubuhan. Pasal 81 ayat (1) Perppu No. 1 Tahun 2016 berbunyi, "Setiap orang yang melanggar ketentuan sebagaimana dimaksud dalam Pasal 76 D dipidana dengan pidana penjara paling singkat 5 (lima) tahun dan paling lama 15 (lima belas) tahun dan denda paling banyak Rp. 5.000.000.000 (lima milyar rupiah)". Terlihat jelas bahwa Pasal tersebut merujuk kembali ke Pasal 76 D Undang-Undang No. 23 Tahun 2002 Jo. Undang-Undang No. 35 Tahun 2014 tentang Perlindungan Anak yang berbunyi, "Setiap orang dilarang melakukan kekerasan atau ancaman kekerasan memaksa anak melakukan persetubuhan denganya atau dengan orang lain". Inilah yang menjadi perbedaan mendasar dengan Pasal 82 ayat (1) Perppu No. 1 Tahun 2016. Terlihat jelas juga Pasal tersebut merujuk ke Pasal 76 E Undang-Undang No. 23 Tahun 2002 Jo. Undang-Undang No. 35 Tahun 2014 tentang Perlindungan Anak yang berbunyi, "Setiap orang dilarang melakukan kekerasan atau ancaman kekerasan, memaksa, melakukan tipu muslihat, melakukan serangkaian kebohongan, atau membujuk anak untuk melakukan atau membiarkan dilakukan perbuatan cabul."

Pada hakikatnya antara pidana pokok, pidana tambahan dan pidana tindakan perbedaanya dapat dilihat melalui gradasi pidananya. Pidana pokok merupakan pidana paling terberat dengan tujuan memberikan efek jera, seperti perampasan hak dasar berupa hak hidup (pidana mati), hak kebebasan (pidana penjara), dan hak milik (pidana denda). Sementara pidana tambahan yang tujuanya bermaksud memberikan penderitaan kepada pelaku, gradasi hukumnya lebih ringan dari hukuman pidana pokok, sebab lazimnya hanya merampas hak yang terkait dengan kepentingan negara, tidak sampai menangguhkan hak yang sifatnya kodrati. Pidana tambahan dalam Pasal 10 huruf (b) KUHP bisa menjadi contoh di antaranya yaitu 
pencabutan hak-hak tertentu (hak politik, hak perwalian), perampasan barangbarang tertentu, dan pengumuman putusan hakim. Berbeda dengan pidana tindakan yang berpijak dari filosofi pemidanaan perawatan dan pemulihan terhadap pelaku kejahatan, sehingga tingkat pemidanaannya lebih ringan dari pidana tambahan. Pidana tindakan biasanya pelaku hanya diberikan pendidikan dan pengajaran melalui lembaga pembinaan pemerintah.

Dalam konteks pidana kebiri, baik dari gradasi pidananya maupun metode pemidanaanya harus didapati bahwa pidana pokok telah menyimpangi prinsip pemidanaan. Pidana kebiri tiada lain sebagai perampasan hak fundamental berupa hak untuk berkeluarga serta bertentangan dengan filosofi pidana tindakan yaitu pelaku hanya diberikan pendidikan dan pengajaran, bukan pidana badan. Maka dengan itu lebih tepat pidana kebiri dikualifikasikan sebagai pidana pokok saja. Apabila pidana kebiri ditempatkan sebagai pidana tindakan, lalu diakumulasikan dengan pidana pokok, maka sama saja mengacau-balaukan filosofi pemidanaan antara bermaksud memberi efek jera atau hendak memulihkan sikap dan keadaan mental pelaku.

\section{Relevansi Pidana Kebiri Dalam Teori Pemidanaan}

Masalah pokok dalam hukum pidana berkenaan dengan tiga hal, yaitu: masalah perbuatan pidana, masalah kesalahan/pertanggungjawaban pidana, serta masalah pidana dan pemidanaan. Kaitannya dengan ketiga masalah pokok hukum pidana di atas, ilmu hukum pidana yang dikembangkan dewasa ini lebih banyak membicarakan masalah-masalah dogmatik hukum pidana daripada sanksi pidana. Pembahasan tentang sanksi pidana yang bersifat memperkokoh norma hukum pidana belum banyak dilakukan, sehingga pembahasan seluruh isi hukum pidana dirasakan masih belum serasi (Moelyatno, 2009: 59).

Andi Hamzah berpendapat bahwa pidana dan pemidanaan bukan hanya berkaitan erat dengan hukum pidana, tetapi menjadi masalah inti hukum pidana. Namun, masalah pidana dan pemidanaan menurut Bambang Pornomo, dianggap merupakan suatu bentuk yang tak banyak diketahui, sehingga pembahasan tentang ilmu hukum pidana dan menyoroti pidana pada umumnya dan pidana penjara pada khususnya kurang mendapat perhatian. Selama ini yang banyak dipersoalkan dalam ilmu hukum pidana terletak di bidang asas-asas hukum pidana yang menyangkut perbuatan pidana dan pertanggungjawaban pidana, yang pada dasarnya terletak di luar bidang pidana dan sistem pemidanaan (Hamzah, 1993: 9).

Pada tataran sosiologis dan praktik penegakan hukum pidana, istilah pidana juga sering memakai istilah "hukuman". Istilah yang akan didiskursuskan ini sebenarnya merupakan terjemahan dari istilah Belanda, yaitu "straf". KUHP yang merupakan singkatan dari Kitab Undang-Undang Hukum Pidana, juga merupakan terjemahan dari istilah Belanda yaitu WvS (Wetboek van Strafrecht). Apabila straf diterjemahkan ke dalam Bahasa Indonesia menjadi "hukuman", maka terjemahan WvS ke dalam bahasa Indonesia seharusnya bukan KUHP, melainkan adalah KUHH (Kitab Undang-Undang Hukum Hukuman) (Widodo, 2009: 53). 
Selain dari sudut pandang istilah seperti diuraikan di atas, terdapat perbedaan dari sisi cakupan yang terkandung pada istilah tersebut. Cakupan istilah hukuman lebih luas dari pada cakupan istilah pidana. Istilah hukuman dapat digunakan dalam banyak bidang, seperti bidang hukum perdata, bidang hukum administrasi, bidang hukum perburuhan dan bahkan juga di bidang pendidikan pun juga sering digunakan istilah hukuman. Seperti contohnya penggunaan istilah hukuman di bidang pendidikan: pada saat seorang guru menyuruh muridnya untuk berdiri di depan kelas karena tidak mengerjakan PR (Pekerjaan Rumah), atau dengan cara memukul sang murid dengan lidi, semua itu merupakan hukuman, tidak pernah digunakan istilah pidana. Berdasarkan penjelasan tersebut, maka menurut penulis hukuman merupakan istilah yang bersifat general, sedangkan pidana merupakan istilah yang spesifik, yaitu khusus digunakan dalam bidang hukum pidana. Namun demikian, dari sudut praktik penegakan hukum tidak mempunyai arti yang signifikan untuk diperdebatkan dalam penggunaan antara istilah pidana dan hukuman, akan tetapi dalam tataran dunia akademis, terutama dalam rangka konsistensi, maka perbedaan istilah tersebut perlu dan penting untuk diperhatikan. Sehingga penulis memberikan istilah "pidana kebiri", "bukan hukuman kebiri".

Pidana secara harfiah artinya adalah sebuah nestapa atau penderitaan, sedangkan secara yuridis, menurut Roeslan Saleh, pidana artinya adalah reaksi atau delik, dan ini berwujud suatu nestapa yang dengan sengaja ditimpakan negara pada pembuat delik itu. Maka unsur-unsur atau ciri-ciri pidana adalah (Saleh, 1983: 18):

a. Pidana itu pada hakekatnya merupakan suatu pengenaan penderitaan atau nestapa atau akibat-akibat lain yang tidak menyenangkan;

b. Pidana itu diberikan dengan sengaja oleh orang atau badan yang mempunyai kekuasaan/oleh yang berwenang;

c. Pidana itu dikenakan kepada subyek hukum yang telah melakukan perbuatan pidana (yang dapat dipertanggungjawabkan).

Pidana sebagai sebuah nestapa atau penderitaan, maka obyek atau sasaran pengenaanya dalam hal ini ditujukan kepada:

a. Ditujukan terhadap jiwa, seperti pidana mati;

b. Ditujukan terhadap badan, seperti pidana cambuk, pidana kebiri dan sebagainya;

c. Ditujukan terhadap kemerdekaan atau kebebasan, seperti pidana penjara, pidana kurungan, pidana pembuangan;

d. Ditujukan terhadap harta benda, seperti pidana denda

Mengingat pidana merupakan suatu penderitaan yang tidak menyenangkan, karena memang hukum pidana memberikan sanksi yang bengis dan sangat memperkuat berlakunya norma-norma hukum yang telah ada, tetapi tidak mengadakan norma yang baru, maka atas dasar inilah Kant menyebut bahwa hukum pidana sesungguhnya adalah hukum sanksi. Sehubungan dengan sifat pidana yang memberi akibat pada penderitaan atau hal-hal yang tidak menyenangkan, maka itulah sebabnya pidana diposisikan sebagai ultimum remidium yang artinya adalah bahwa sanksi pidana merupakan "senjata" atau upaya terakhir setelah upaya-upaya 
lain gagal dalam menanggulangi suatu perbuatan. Demikian halnya dengan posisi sanksi pidana juga berkedudukan sebagai ultimum remidium dalam pengertian apabila upaya-upaya atau usaha-usaha lain gagal dalam mencegah suatu perbuatan yang tidak dikehendaki. Upaya-upaya lain yang dimaksud dalam hal ini bisa menggunakan sanksi perdata, sanksi administratif, sanksi sosial. Apabila sanksisanksi ini tidak mempan, maka alternatif terahir adalah dengan menggunakan sanksi pidana yaitu dengan melakukan kriminalisasi terhadap perbuatan tersebut (Kelsen, 2008: 57).

Barda Nawawi Arief menguraikan alasan mengapa pidana harus diposisikan sebagai ultimum remidium, yaitu karena hukum pidana juga mempunyai batas-batas kemampuan sebagai sarana/saluran kebijakan kriminal. Itu semua dikarenakan oleh hal-hal sebagai berikut (Arief, 2011: 24):

a. Sebab-sebab kejahatan yang demikian kompleks berada di luar jangkauan hukum pidana;

b. Hukum pidana hanya merupakan bagian kecil (subsistem) dari sarana kontrol sosial yang tidak mungkin mengatasi masalah kejahatan sebagai masalah kemanusiaan dan kemasyarakatan yang sangat kompleks sifatnya;

c. Penggunaan hukum pidana dalam menanggulangi kejahatan hanya merupakan "obat simptomatik" bukan "pengobatan kausatif", artinya penggunaan hukum pidana merupakan penanggulangan suatu gejala dan bukan suatu penyelesaian dengan menghilangkan sebab-sebabnya;

d. Sanksi hukum pidana merupakan "remidium" yang mengandung sifat kontradiktif/paradoksial dan mengandung unsur-unsur serta efek samping yang negatif;

e. Sistem pemidanaan bersifat fragmentair dan individu/personal, tidak bersifat struktural dan fungisonal;

f. Keterbatasan jenis sanksi pidana dan sistem perumusan sanksi pidana yang bersifat kaku dan imperatif;

g. Bekerjanya hukum pidana memerlukan sarana pendukung yang lebih bervariasi dan lebih menuntut "biaya tinggi."

Selain hal tersebut di atas, dalam sejarah perkembangan hukum pidana dapat diungkapkan tiga macam teori yang mengemukakan tujuan pemidanaan, yaitu teori absolut (velgeding theorien), teori relatif (doel theorien), dan teori gabungan (vernengings theorien). Teori tersebut mengkaji tentang alasan pembenar penjatuhan pidana. Menurut teori absolut pidana dijatuhkan oleh negara kepada siapa saja yang melakukan kejahatan setimpal dengan perbuatanya. Pidana dijatuhkan semata-mata berdasarkan pembalasan atas perbuatanya. Pidana tidak diorientasikan pada masa depan narapidana, tetapi didasarkan pada masa lalu penjahat. Tujuan pidana adalah menjadikan penjahat menderita. Sedangkan menurut teori relatif pidana dijatuhkan untuk kepentingan masa depan narapidana dan masyarakat dalam rangka menjamin ketertiban umum. Pidana merupakan sarana memperbaiki penjahat agar tidak melakukan kejahatan kembali sekaligus memberikan peringatan kepada masyarakat agar tidak melakukan kejahatan. 
Sementara teori gabungan mengutamakan pembedaan perlakuan antara penjahat satu dengan penjahat lainya, termasuk pembedaan sifat delik yang dilakukan. Hal ini digunakan sebagai pertimbangan dalam menerapkan unsur pembalasan sekaligus memperbaiki penjahat dalam rangka mencapai tatanan masyarakat yang tertib dan damai (Widodo, 2009: 70).

Jika dilihat, pidana kebiri memang seolah menjadi suatu jenis pemidanaan yang sadis, namun sesungguhnya tidaklah sesadis apa yang dilakukan oleh si pelaku terhadap korban. Para korban yang telah hancur masa depanya, mereka telah hilang kehormatanya dan mengalami depresi yang berkepanjangan, sehingga pidana kebiri adalah pidana yang pantas diberikan kepada pelaku. Pidana kebiri bagi pelaku pedofilia tidak diartikan sebagai hukuman permanen seumur hidup. Bukan dibuang testisnya melainkan dengan metode suntik untuk mengurangi syaraf libido pelaku. Melalui cara itu, pelaku pedofilia diharapkan mampu meredam hawa nafsu akan kebutuhan seks (Agung, "Menyoal Pidana Kebiri", www.hukumpedia.com/agungh28/menyoal-pidana-kebiri, diakses pada Minggu, 26 Juni 2016, jam 19.00 wib).

Menilik Negara-negara yang menerapkan pidana kebiri seperti Belanda, Jerman, Perancis, Belgia, Swedia, Denmark dan Ceko, para pelaku kejahatan seksual boleh memilih hukuman baginya, apakah dipenjara untuk waktu yang lama atau dikebiri. Hasil riset di Skandinavia menyatakan penerapaan kebiri mengurangi tingkat pengulangan kejahatan seksual oleh pelaku yang sama hingga $35 \%$. Kastrasi kimia pertama di Asia terhadap pelaku kejahatan seksual diperkenalkan di Korea Selatan lima tahun silam. Berdasarkan payung hukum yang berlaku di sana, kejahatan seks terhadap anak bisa dihukum kebiri kimia. Pada tahun 2013 pemerintah Korea Selatan bahkan merevisi aturan untuk memberlakukan tindakan tersebut pada pelaku. Charles Scott dan Trent Holmberg menyebutkan bahwa California menjadi negara bagian AS pertama yang mengizinkan penerapan kebiri terhadap penjahat seks tertentu yang telah tuntas menjalani masa tahananya. Meski legislasinya disebut-sebut kontroversial, delapan negara bagian lainya di AS mengadopsi praktik serupa untuk masa percobaan residivis ataupun pembebasan bersyarat. Dari total sembilan negara federal di AS empat di antaranya hanya mengizinkan kebiri kimia. Empat negara bagian lainya seperti California, Florida, Lowa, dan Lousiana memperbolehkan kastrasi kimia dan bedah (sukarela). Akan tetapi kebiri kimia harus dilakukan berulang kali, selain itu menimbulkan efek samping. Kasus di Australia menunjukan bahwa pemberian obat penekan libido bisa mengakibatkan penyakit jantung, osteoprosis, dan pembesaran payudara (Scott dan Holmberg, 2003: 502).

Pemberlakuan pidana kebiri sudah sewajarnya dalam konteks pemidanaan pelaku. Setelah putusan pengadilan berkekuatan hukum tetap (incracht) yang menyatakan pelaku divonis pidana kebiri, maka dokter akan memberikan suntikan cairan kimia tertentu dalam rangka mengeksekusi terpidana atas vonis hakim. Hal ini sesuai demi menciptakan ketertiban masyarakat dan menciptakan lingkungan 
yang nyaman tempat tumbuhnya dan berkembangnya anak-anak dan menjamin masa depan anak-anak Indonesia.

Terkait dengan relevansi pidana kebiri di Indonesia dalam teori pemidanaan menurut penulis adalah relevan menjadi alternatif pidana terakhir bagi pelaku kejahatan seksual. Untuk membuat pidana kebiri ini lebih efektif, lebih baik jika ditambahkan dengan sebuah terapi yang merubah perilaku kekerasanya dan perilaku seksualnya. Ini sejalan dengan konsepsi tujuan pemidanaan dari teori gabungan yang menyatakan bahwa selain menerapkan unsur pembalasan tetapi juga untuk memperbaiki pelaku pedofilia agar tidak melakukan kejahatan kembali. Dalam teori gabungan konsepsi pemidanaan perlu adanya pemilahan antara tahaptahap pemidanaan yang berbeda-beda, misalnya pada ancaman pidana dalam undang-undang proses penuntutan, proses peradilan, serta pelaksanaan pidana. Pada setiap tahap perlu ada asas-asas tertentu yang diprioritaskan. Jaksa di dalam mengemukakan tuntutan pidana misalnya dalam tindak pidana kategori berat dapat mengutamakan unsur pembalasan. Pada tahap pelaksanaan pidana perlu pula memperhatikan resosialisasi terpidana.

Menurut RKUHP Indonesia Tahun 2015, juga menganut teori gabungan. Hal ini tampak pada tujuan pemidanaan, yaitu sebagai sarana pencegahan, pembinaan dan pemulihan ketertiban masyarakat, serta sarana pembebasan rasa bersalah pelaku tindak pidana, hal ini dituangkan dalam Bagian ke Satu Paragraf I Pasal 54 yang mengatur tentang tujuan pemidanaan, yaitu:

1) Pemidanaan bertujuan:

a. Mencegah dilakukanya tindak pidana dengan menegakan norma hukum demi pengayoman masyarakat;

b. Memasyarakatkan terpidana dengan mengadakan pembinaan sehingga menjadi orang yang baik dan berguna;

c. Menyelesaikan konflik yang ditimbulkan oleh tindak pidana, memulihkan keseimbangan dan mendatangkan rasa damai dalam masyarakat, dan;

d. Membebaskan rasa bersalah pada terpidana.

2) Pemidanaan tidak dimaksudkan untuk menderitakan dan merendahkan martabat manusia.

Untuk merealisasikan tujuan pemidanaan tersebut dalam RKUHP tahun 2007 ditentukan jenis-jenis pidana Pasal 66 sebagai berikut:

1) Pidana pokok terdiri atas:

a. Pidana penjara;

b. Pidana tutupan;

c. Pidana pengawasan;

d. Pidana denda;dan

e. Pidana kerja sosial

2) Urutan pidana sebagaimana dimaksud pada ayat (1) menentukan berat ringanya pidana

Sementara pada Pasal 67, pidana mati merupakan pidana pokok yang bersifat khusus dan selalu diancamkan secara alternatif:

1) Pidana tambahan terdiri atas

a. Pencabutan hak-hak tertentu; 
b. Perampasan barang tertentu dan/atau tagihan

c. Pengumuman putusan hakim;

d. Pembayaran ganti kerugian; dan

e. Pemenuhan kewajiban adat setempat dan/atau kewajiban menurut hukum yang hidup dalam masyarakat.

2) Pidana tambahan dapat dijatuhkan bersama-sama dengan pidana pokok, sebagaimana pidana yang berdiri sendiri atau dapat dijatuhkan bersamasama dengan pidana tambahan lain.

3) Pidana tambahan berupa pemenuhan kewajiban adat setempat dan/atau kewajiban menurut hukum yang hidup dalam masyarakat atau pencabutan hak yang diperoleh korporasi dapat dijatuhkan walaupun tidak tercantum dalam perumusan tindak pidana.

4) Pidana tambahan untuk percobaan dan pembantuan adalah sama dengan pidana tambahan untuk tindak pidananya.

Berdasarkan dari KUHP yang sekarang maupun RKUHP di atas, pidana kebiri memang belum ada dalam sistem pemidanaan di Indonesia. Indonesia sementara ini baru memunculkan literatur perundang-undangan ketentuan mengenai kejahatan seksual terhadap anak yang diatur pada Pasal 290 KUHP dengan ancaman pidana penjara paling lama tujuh tahun. Selanjutnya, ketentuan khusus yang mengakomodir kepentingan anak diatur dalam UU No. 23 Tahun 2002 Jo. UU No. 35 Tahun 2014 tentang Perlindungan Anak dengan ancama pidana penjara paling lama 15 tahun dan paling singkat tiga tahun serta denda paling banyak Rp 300.000.000. Kemunculan Perppu No. 1 Tahun 2016 menjadi alternatif pidana baru dan bisa merevisi RKUHP 2015, khususnya Pasal 103 untuk menambahkan pidana kebiri ke jenis pidana tindakan terhadap pelaku pidana kebiri di Indonesia.

\section{Eksekutor Pidana Kebiri}

Banyak pihak yang menilai pidana kebiri terlalu keji dan tidak manusiawi, tidak mendidik, serta merendahkan derajat dan martabat manusia. Ada juga yang berpendapat pidana kebiri diberlakukan karena desakan masyarakat sehingga beraroma dendam dan subyektif. Terakhir muncul penolakan dari dokter, dalam hal ini Ikatan Dokter Indonesia (IDI), untuk menyuntik pelaku pedofil dengan zat kimia. Dokter menolak menjadi eksekutor pidana kebiri dengan alasan bertentangan dengan kode etik (KODEKI). Sesuai kode etik, seorang dokter harus menjadi pelindung kehidupan sesuai dengan Pasal 11 Kode Etik Kedokteran. Seorang dokter harus mengerahkan segala kemampuanya untuk memelihara kehidupan alamiah pasienya dan tidak untuk mengakhirinya. Selain itu, terdapat tiga asas alasan utama dokter (IDI) menolak menjadi eksekutor kebiri, yaitu (Sobirin, 2017: ):

a. Asas manfaat

Berdasarkan asas ini melakukan kebiri tidak memiliki manfaat sama sekali. Dengan demikian apabila kebiri dilakukan oleh seorang dokter ia akan melanggar etik. Dari aspek medis teknis pelaksanaan tidaklah sederhana, perlu melibatkan dokter ahli bedah, ahli anastesi, dan ahli kedokteran jiwa.

b. Asas jangan mencederai atau jangan merugikan

Prinsip ini menjadi penegasan asas manfaat. Asas ini berlaku dari segala aspek kehidupan, jangan mencederai dari segi spiritual (hak beribadah), 
jangan mencederai dari aspek psikologi yaitu kewajiban menyimpan rahasia kedokteran, aspek finansial jangan sampai pasien mengeluarkan biaya yang tidak diperlukan. Jika direlevansikan dengan pidana kebiri, pelaku dalam hal ini pasien sangat dirugikan karena kehilangan hak berketurunan. Hak berketurunan sejatinya ciptaan Tuhan, jika manusia menghalangi itu dengan paksa, maka sama saja menentang kehendak tuhan.

c. Asas Otonomi

Mensyaratkan segala pikiran pertimbangan dan keputusan dokter yang akan dikerjakan wajib diketahui, disadari, dan disetujui oleh pasien. Bahkan untuk tindakan yang berpotensi merusak jaringan diperlukan surat persetujuan tertulis.

Kode etik dibuat sebagai rambu-rambu bagi anggota organisasi profesi. Sifatnya mengikat dan wajib dipatuhi oleh seluruh anggotanya. Bagi anggota yang melanggar bisa dikenakan sanksi dari mulai yang ringan seperti teguran sampai dengan pemecatan, sehingga wajar jika Ikatan Dokter Indonesia (IDI) menolak, karena pertanggungjawaban eksekusi terhadap pelaku pidana kebiri oleh dokter dipertanggungjawabkan kepada Ikatan Dokter Indonesia (IDI).

Eksekutor yang dapat mengeksekusi terpidana kebiri adalah Kepolisian Republik Indonesia melalui Kedokteran Kepolisian (Dokpol). Karena Dokpol berbeda dengan Ikatan Dokter Indonesia (IDI) berdasarkan kewenangan dan pertanggungjawaban. Seseorang menjadi Dokpol, selain setelah menjadi dokter harus menjalani pendidikan di Sekolah Inspektur Polisi Sumber Sarjana (SIPSS) Akademi Kepolisian. Dokpol sebagai unit kerja Polri, yang profesional di bidangnya menjadi pelaksana eksekutor pelaku pidana kebiri. Peraturan Kepolisan Negara Republik Indonesia No. 12 Tahun 2011 tentang Kedokteran Kepolisian Pasal 1 ayat 1 menyatakan, "Kedokteran Kepolisian yang selanjutnya disingkat Dokpol adalah penerapan ilmu pengetahuan dan teknologi kedokteran beserta ilmu-ilmu pendukungnya untuk kepentingan tugas kepolisian."

Kepentingan tugas kepolisian yang dimaksudkan dalam Peraturan Kepolisian RI No. 12 Tahun 2011 Pasal 1 ayat 1 salah satunya adalah dalam rangka penegakan hukum terhadap pelaku pidana kebiri berdasarkan putusan pengadilan. Kemampuan Dokpol dalam Peraturan Kepolisian RI Pasal 6, di antaranya, yaitu: 1) Olah Kejadian Tempat Perkara (TKP), aspek medis; 2) Patologi Forensik; 3) Antropologi Forensik; 4) Odontologi kepolisian; 5) DNA Profiling; 6) Taksikologi Forensik; 7) Kesehatan Tahanan; 8) Forensik Klinik; 9) Psikiatri forensik; 10) Kedokteran lalu lintas; 11) Hukum kesehatan; 12) Medikolegal; 13) PPT korban kekerasan terhadap perempuan dan anak; 14) Farmasi kepolisian; 15) Keslap; Pengamanan Kesehatan; 16) Pengamanan Makanan; 17) Penanganan penyalahgunaan narkotika; 18) Penanganan bahaya CBRN; 19) Geomedichine; 20) Kesehatan Perpolisian Masyarakat (Kespolmas).

Pertanggungjawaban Dokpol terdapat dalam Peraturan Kepolisian RI No. 12 Tahun 2011 Pasal 13 ayat (1) dan (2), yaitu: 
1) Pengawasan dan pengendalian secara umum terhadap kegiatan Dokpol dilaksanakan:
a. Pada tingkat Mabes Polri oleh Inspektorat Pengawasan Umum (Itwasum) Polri; dan
b. Pada tingkat kewilayahan oleh Inspektorat Pengawasan Daerah (Itwasda) Polda.

2) Pengawasan dan pengendalian teknis terhadap kegiatan dokpol dilaksanakan:

a. Pada tingkat Mabes Polri oleh Kapusdokkes Polri; dan

b. Pada tingkat kewilayahan oleh Kapusdokkes Polda.

Pelaksanaan eksekusi kebiri harus dilakukan nantinya oleh tim khusus yang dibentuk Dokpol. Tanggung jawab etika dan masalah lainya terkait dokpol sudah diambil oleh negara dan aparatur negara hanya sebagai pelaksana. Hal itu harus dilakukan setelah proses sidang yang seadil-adilnya, dengan hakim memegang teguh nilai-nilai keadilan. Pemerintah sudah mengeluarkan Perppu No. 1 Tahun 2016 tentang perlindungan Anak yang tujuanya adalah untuk melindungi anak-anak Indonesia dari perilaku kekerasan seksual yang keji serta nantinya akan ada tiga Peraturan Pemerintah di perppu tersebut yakni Rehabilitasi Sosial, Kebiri, dan Pemasangan Chip.

\section{PENUTUP \\ 1. KESIMPULAN}

Dari ketentuan Pasal 81 Ayat 7 Perppu No. 1 Tahun 2016 tentang Perubahan Kedua atas Undang-Undang No. 23 Tahun 2002 tentang Perlindungan Anak menjadi jenis Pemidanaan baru di Indonesia yaitu Pidana Kebiri yang termasuk dalam Pidana Tindakan. Pidana kebiri ini menjadi alternatif pidana terakhir (ultimum remidium) bagi pelaku pedofilia. Hal ini relevan dilakukan karena dengan maraknya kasus-kasus kekerasan seksual pada anak di Indonesia, agar memberikan efek jera bagi pelaku pedofilia dan pemulihan kepada pelaku pedofilia agar tidak mengulangi kejahatan yang sama. Hal ini sejalan dengan tujuan pemidanaan dari Teori Gabungan untuk memberikan efek jera kepada pelaku, namun juga memberikan pembinaan dan pemulihan kepada pelaku pedofilia serta mengingatkan kepada masyarakat untuk tidak berbuat tindak pidana tersebut. Sementara itu, eksekutor terhadap terpidana kebiri dilakukan oleh Kepolisian Republik Indonesia melalui dokter kepolisian (dokpol). Pertanggungjawaban Dokpol bukan terhadap Ikatan Dokter Indonesia melainkan kepada Negara.

\section{SARAN}

Dari berbagai permasalahan yang diuraikan, penulis memberikan saran, demi keadilan, kemanfaatan, dan kepastian hukum bagi pelaku, maka Pemerintah dalam hal membuat peraturan perundang-undangan maupun membuat keputusan harus berlandaskan pada asas-asas hukum pidana dan tujuan pemidanaan. Harapanya di Indonesia kejahatan seksual dapat dikurangi bahkan diberantas dengan adanya pidana kebiri, sama seperti negara-negara lain, seperti Skandinavia. Kemudian dari pihak yang melakukan eksekusi pidana kebiri terhadap pelaku (Dokter Kepolisian 
[Dokpol]) perlu dibentuk tim khusus dari Dokter Kepolisian (Dokpol) untuk pelaksanaan eksekusi terhadap terpidana kebiri. Demikian pula perlu revisi terhadap Peraturan Kepolisian Republik Indonesia No. 12 Tahun 2011 tentang Kedokteran Kepolisian untuk menambahkan kemampuan Dokter Kepolisian dan penambahan kewenangan Dokter Polisi sebagaii eksekutor pada Peraturan Pelaksana (PP).

\section{DAFTAR PUSTAKA}

\section{A. BUKU DAN JURNAL}

Arief, Barda Nawawi (2010). Bunga Rampai Kebijakan Hukum Pidana. Jakarta: Kencana.

(2011). Perkembangan Sistem Pemidanaan di Indonesia. Semarang: Pustaka Magister Undip.

Djamali, Abdoel (2007). Pengantar Hukum Indonesia. Jakarta: Raja Grafindo Persada.

Hamzah, Andi (1993). Sistem Pidana dan Pemidanaan Indonesia. Jakarta: Pradnya Paramita.

Irianto, Koes (2010), Memahami Seksologi. Bandung: Sinar Baru Algensindo.

Kelsen, Hans (2008). Teori Hukum Murni, Dasar-Dasar Ilmu Hukum Normatif. Bandung: Nusa Media.

Malian, Sobirin (2017). Analisis Keunikan Dan "Missing Link" Antara Hukum Pidana Internasional, Etika Profesi, Dan Politik; Telaah Kritis Perppu Nomor 1 Tahun 2016 Tentang Perubahan Atas Uu Nomor 23 Tahun 2002 Tentang Perlindungan Anak. Jurnal Ilmu Hukum Novelty, Vol. 7, No. 2.

Saleh, Roeslan (1983). Stelsel Pidana Indonesia. Jakarta: Aksara Baru.

Scott, Charles L (2003). Castraction of Sex Offenders: Prisoners' Right Versus Public Safety. The Journal of The American Academy of Psychiatry and the Law, Vol. 31, No. 4.

Tongat (2010). Pidana Kerja Sosial dan Pembaharuan Hukum Pidana Indonesia. Jakarta: Djambatan

Widodo (2009). Sistem Pemidanaan Dalam Cyber Crime. Yogyakarta: Leksbang Mediatama.

\section{B. PERATURAN PERUNDANG-UNDANGAN}

Perppu No. 1 Tahun 2016 Tentang Perubahan Kedua Atas Undang-Undang No. 23

Tahun 2002 
R. Soesilo (1995). Kitab Undang-Undang Hukum Pidana (KUHP), serta KomentarKomentarnya Lengkap Pasal Demi Pasal. Bogor: Politea.

Rancangan Undang-Undang-Kitab Undang-Undang Hukum Pidana (RUU-KUHP) Tahun 2015 Tentang Perlindungan Anak

UU No. 23 Tahun 2002 Jo. UU No. 35 Tahun 2014 Tentang Perlindungan Anak

\section{INTERNET}

http://m.liputan6.com/showbiz/read/2439571/begini-kronologi-dugaanpelecehan-yang-dilakukan-saipul-jamil

http://hukumpedia.com/agungh28/menyoal-pidana-kebiri

http://Megapolitan.kompas.com/read/2016/05/16/13480371/Ini.Kronologi.Pemb unuhan.EF.Perempuan.yang.Tewas.Mengenaskan.di.Tangerang

http://m.kompasiana.com/ariefzulfian/kronologis-kasus-

jis_55e5775622afbd26054e49da

http://Jogja.tribunnews.com/2013/04/19/ini-kisah-tragis-siswi-smk-yang-

diperkosa-lalu-dibakar-2-kali

http://voaindonesia.com/a/kpai-kekerasan-seksual-terhadap-anak-sudahdarurat/1902840.html

http://m.okezone.com/read/2016/05/04/340/1380243/ini-kronologipemerkosaanyuyun-di-Bengkulu

http://health.kompas.com/read/2015.10/22/120535623/Yang.Terjadi.jika.seseora ng.Dihukum.Kebiri

http://m.dw.com/id/pemerkosaan-berjamaah-Indonesia-darurat-kekerasanseksual/a-19233807

http://m.detik.com/news/berita/2583289/ini-9-negara-yang-menerapkan-sanksikebiri-untuk-pelaku-kejahatan-seks/4\#detailfoto 